Reply to the comments by Pillai, S. P., George, B. G., Ray, J. S., and Kale, V. S., (GJ-19-0112) on Paper: "Depositional history and provenance of cratonic "Purana" basins in southern India: A multipronged geochronology approach to the Proterozoic Kaladgi and Bhima basins" by Joy et al., 2018.

\author{
Sojen Joy ${ }^{1}$ Sarbani Patranabis-Deb ${ }^{2}$ Dilip Saha ${ }^{2}$ Hielke Jelsma ${ }^{1,3}$ Roland Maas $^{4}$ Ulf Söderlund ${ }^{5,6}$ \\ Sebastian Tappe ${ }^{1,7}$ Gert van der Linde $^{1}$ Amlan Banerjee ${ }^{2}$ Unni Krishnan $^{1}$ \\ ${ }^{1}$ De Beers Group Exploration, 59 Crownwood Road, Johannesburg, South Africa \\ ${ }^{2}$ Geological Studies Unit, Indian Statistical Institute, Kolkata, India \\ ${ }^{3}$ Anglo American Group Discovery and Geosciences, 45 Main Street, Johannesburg 2001, South Africa \\ ${ }^{4}$ University of Melbourne, Australia \\ ${ }^{5}$ Department of Geology, Lund University, Solvegatan, 12 SE-22362, Lund, Sweden \\ ${ }^{6}$ Department of Geosciences, Swedish Museum of Natural History, Stockholm, Sweden \\ ${ }^{7}$ Department of Geology, University of Johannesburg, Auckland Park 2006, South Africa
}

\title{
Correspondence
}

Sojen Joy, De Beers Group Exploration, 59 Crownwood Road, Johannesburg, South Africa. Email: sojen.joy@debeersgroup.com

\begin{abstract}
We thank Patil Pillai et al., for preparing a critique on our article (Joy et al., 2018). Patil Pillai et al. contest the analytical procedure utilised for the carbonates and "geological information" documented in our research article and raise concerns on our conclusions. We hereby provide our reply to each of their comments.
\end{abstract}

\section{REPLY TO COMMENTS}

\section{Comment 1}

We recognize that multiple (sometimes conflicting) stratigraphic terms are used in the Kaladgi Basin, but it was not the aim of Joy et al. (2018) to attempt a resolution of such problems. We have followed the stratigraphic division adopted in the latest Geological Survey of India geological map accompanying GSI Memoir 129 (Jayaprakash, 2007) and have retained the stratigraphy and nomenclature as used in Saha et al. (2016). We prefer not to use the rank name Supergroup, as new geochronological data reported in our work shows a hiatus of $\sim 1000$ Myr between the Kaladgi Group (sensu Jayaprakash, 2007) and the Badami Group.

As for the spelling of the name "Simikeri", we should have been more consistent in the two occurrences within the text. We apologise for that error from our side.

This is the author manuscript accepted for publication and has undergone full peer review but has not been through the copyediting, typesetting, pagination and proofreading process, which may lead to differences between this version and the Version of Record. Please cite this article as doi: $10.1002 / \mathrm{gj} .3546$

This article is protected by copyright. All rights reserved. 


\section{Comment 2}

The focus of the Joy et al. (2018) paper is to present new and comprehensive geochronological data for the Kaladgi and Bhima basins using multiple isotope systematics. Thus, the lithological and petrographic descriptions were kept to a minimum and have been generalized in the text. Details of the samples are provided in Table 1 . The description is a mixture of literature augmented with a summary of field observations (explained in section 2.1). We have also guided the reader to the relevant literature in the section.

\section{Comment 3}

There are no actual paleocurrent data presented in the references cited in the critique and it is difficult to judge the number of measurements and actual locations. Our data, mainly from the southern part of the basin, show that the palaeocurrent pattern changes as one goes up in the stratigraphy, drastically so in the Badami and Bhima groups. We have also shown that there are bimodal palaeocurrent directions in some of the measured sections (Figure 6).

\section{Comment 4}

Figures 6 and 7 are perfectly legible in the online version. Table 1 in Joy et al. (2018) omits longitude values for some sample locations and a supplementary data table is provided with this reply (Table R1). Figures 6 and 7 are not intended to find the locations of the samples, as they were provided in Table 1.

\section{Comment 5}

The GPS coordinates of sample site EHW667 for the dolerite dyke is provided in Table 1 $\left(75.29789^{\circ} \mathrm{E}, 16.16362^{\circ} \mathrm{N}\right)$. To reiterate for the benefit of the readers, the dolerite is intruded into the Hebbal argillite member, Yendigere Formation (middle part of the Kaladgi Group). This is stated clearly in Table 1 and in the text (section 4.1).

\section{Comment 6}

Patil Pillai et al. correctly point out the importance of choosing a gentle acid leaching protocol for radiogenic (e.g. Sr-Pb) isotopic work on impure carbonates. However, this is no guarantee that the resulting carbonate fractions are completely free of 'detrital' impurities, an uncertainty that affects most solution-mode radiogenic isotope studies of old limestones to some extent. Hydrofluoric acid was used here only to produce bulk (carbonate + silicate) dissolutions, i.e. would not qualify as 'baffling'. The use of $2 \mathrm{M} \mathrm{HNO}_{3}$ to produce the carbonate fractions may be viewed as 'too harsh' because less aggressive alternatives (Patil Pillai et al. mention acetic and hydrobromic acid) are available. In the case of the silicified Katageri Limestone samples, initial attempts to generate carbonate fractions with $10 \%$ acetic acid produced leachates with insufficient $\mathrm{Pb}$ for precise analysis. Even with $2 \mathrm{M} \mathrm{HNO}_{3}$, a long reaction time with mild heating was required to generate 'carbonate' fractions of suitable size. In section 5.3 we acknowledge that detrital effects may still be present. The Bhima Basin limestone samples were more reactive and were thus treated briefly with cold $2 \mathrm{M}$ $\mathrm{HNO}_{3}$. Trace element data for the carbonate fractions (not published in Joy et al. 2018 for space reasons) show some hallmarks of marine carbonates, such as mild Ce depletion, high LREE/HFSE, low Rb/Sr, high $\mathrm{Ca}$ and low $\mathrm{Ti}$. In obviously complex open systems such as these limestones, this was considered encouraging, and the $\mathrm{HNO}_{3}$ extracts were thus used for the $\mathrm{Pb}-\mathrm{Sr}$ isotope work. 
Patil Pillai et al. also note that $\mathrm{U}-\mathrm{Th}-\mathrm{Pb}$ isotope dispersions in the $\mathrm{HNO}_{3}$-fractions and the bulk dissolutions for Katageri Limestone show considerable overlap. With respect to Figure 15 , we suggested that scattered but near-linear ${ }^{238} \mathrm{U}-{ }^{206} \mathrm{~Pb}$ and ${ }^{235} \mathrm{U}-{ }^{207} \mathrm{~Pb}$ (not shown) trends defined by the data points for the bulk fractions (silicate + carbonate) provide an apparent $0.96 \mathrm{Ga}$ age constraint for the limestones. Patil Pillai et al. argue that this is invalid because detrital components of possibly diverse provenance should not define a valid isochron. This may be so, but it is also possible that extensive silicification has had a smoothing effect on $\mathrm{U}-\mathrm{Pb}$ systems in the detrital phases which dominate the U-Pb mass budget in the total dissolutions. A high 'initial' ${ }^{206} \mathrm{~Pb} /{ }^{204} \mathrm{~Pb}$ ratio of ca. 24.5 would be consistent with this inferred resetting event. In this scenario, the $0.96 \mathrm{Ga}$ 'age' might possibly provide an estimate for the time of silicification. The discussion of this age (section 7.3) reflects the geological uncertainties of these results.

The caption for Figure 15b describes this figure as a Th-Pb isochron diagram, it does not mention a Th- $\mathrm{Pb}$ isochron calculation. This sort of misreading also reappears later in Patil Pillai et al.'s comments.

Our U-Th-Pb isotope results for the Bhima Basin limestones (based on short-duration cold leaches to produce the carbonate fractions) are quite different from those for the Kaladgi Basin. To our surprise, the $\mathrm{U} / \mathrm{Pb}$ and uranogenic $\mathrm{Pb}$ isotope ratios in these fractions cluster tightly and provide little useful age information. For this reason, $\mathrm{Sr}$ isotope data were acquired, with the hope that samples with the least detrital influence would preserve a depositional marine ${ }^{87} \mathrm{Sr} /{ }^{86} \mathrm{Sr}$ signal. While Patil Pillai et al. summarily dismiss the $\mathrm{Sr}$ isotope results, presumably on the basis of their earlier comments about possible detrital influence in our $\mathrm{HNO}_{3}$ fractions, we are encouraged by (i) the low $\mathrm{Rb} / \mathrm{Sr}$ ratio, (ii) the general trace element patterns which are very carbonate-like (see above), and (iii) broad agreement of our inferred $\mathrm{Sr}$ isotope age with the Th- $\mathrm{Pb}$ systematics (see below). The ${ }^{87} \mathrm{Sr} /{ }^{86} \mathrm{Sr}$ systems in these carbonate fractions clearly do contain detrital Sr but the trend in Figure 17a suggests that at least some samples record near-primary (marine) ratios which can be used to derive a likely age range. We note that an even lower ${ }^{87} \mathrm{Sr} /{ }^{86} \mathrm{Sr}$ value (near 0.705 ) would still yield the kind of Neoproterozoic marine-Sr age we inferred in our paper.

\section{Comment 7}

Th- $\mathrm{Pb}$ systematics in low-temperature calcite are indeed unsuitable for dating, with very low Th/U (but see the study of Brannon et al., 1996 on ore-related, higher temperature calcite for an interesting contrast). It is clear in this case that high Th in the Bhima Basin is likely to be from detrital material. We also note that the $\mathrm{HNO}_{3}$ fractions from 16 rock samples in two different limestone formations all plot around the same ${ }^{232} \mathrm{Th}-{ }^{208} \mathrm{~Pb}$ trend. The age equivalent to the slope of this line is $0.91 \pm 0.13 \mathrm{Ga}$, broadly consistent with the $\mathrm{Sr}$ isotope results discussed above. The initial ${ }^{208} \mathrm{~Pb} /{ }^{204} \mathrm{~Pb}$ ratio of this Th- $\mathrm{Pb}$ trend $(37.5 \pm 0.3)$ is also consistent with a Neoproterozoic age. If Th is attributed to detrital material in these limestones, then so should the thorogenic $\mathrm{Pb}$ it correlates with so clearly. In this case, the detrital material, or its isotopic homogenization, would be dated by this $0.91 \pm 0.13 \mathrm{Ga}$ trend, providing a possible depositional age for the limestone. 
The limestone results presented in Joy et al. (2018) are complicated, and each of the arguments made here can be challenged. In our evaluation of this data set, we tried to keep an open mind rather than dismiss everything because it does not fit established patterns.

\section{Comment 8}

Regarding the detrital zircon populations (section 7), we focussed on the major age structure and refrained from trying to explain minor age peaks. The $2.5 \mathrm{Ga}$ source has been discussed in section 7.1.2. Joy et al. (2018) do not advocate absence of Closepet Granite age zircons in the Kaladgi Group clastic rocks. As correctly pointed out by the critique, the detrital zircons spread from $2300 \mathrm{Ma}$ to $2700 \mathrm{Ma}$. The 'Dharwar Craton' provenance referred to in section 7 of our paper was understood (by us) to include Closepet Granite, a major component of the Dharwar Craton. We believed this to be self-evident.

\section{Comment 9}

We strongly disagree with the comments made in Patil Pillai et al. about the Bhima Basin $\mathrm{Rb}-\mathrm{Sr}$ glauconite results. Firstly, the two glauconitic sandstones are described in sections 4.2.1 and 4.2.2 and an authigenic origin is clearly implied for petrographic reasons. The last paragraph had an error in the statement with a "does not" missing (see below).

"An authigenic origin of the glauconite grains is supported by the rare occurrence of slender $\leq 0.1$-mm-long apatite inclusions (i.e., needles). Such brittle apatite needles would not stay intact during grain transport, and thus, their presence does not support a detrital origin of the host glauconite grains".

This is consistent with the widely-held view that glauconite (or glaucony) forms within the sediment from Fe-rich precursor phyllosilicate minerals (e.g. biotite), with a strong seawater influence. The high MSWD for a pooled regression of 4 residue-leachate pairs does flag some geological heterogeneity. The 2-point ages derived from the individual residue-leach pairs show very little age scatter and have an average that is indistinguishable from the pooled regression, and the 2-point ages in both sandstones (EHV956, 957) are very similar. The high $y$-axis intercepts of the 2-point lines $\left({ }^{87} \mathrm{Sr} /{ }^{86} \mathrm{Sr}>0.710\right)$ show some non-marine influence which may very well reflect the complex petrography of the glauconites as described in Joy et al. (2018, section 4.2). In this context, the possibility of age inaccuracy through mixing of non-cogenetic components (see Stille \& Clauer, 1994) must be considered (Patil Pillai et al.'s third point). Single glauconite Rb-Sr model ages are usually calculated by assuming a marine initial ${ }^{87} \mathrm{Sr} /{ }^{86} \mathrm{Sr}$. In our study, we decided to check this and found the leachable $\mathrm{Sr}$ to be at least partially non-marine. However, even with a lower initial ${ }^{87} \mathrm{Sr} /{ }^{86} \mathrm{Sr}$ more appropriate for Proterozoic seawater, the glauconite model ages only shift by $20 \mathrm{Ma}$. In a reconnaissance study of a long-lived sedimentary basin with very limited existing age control, these glauconite ages provide a powerful age constraint. We see no reason to dismiss our glauconite-based age estimates as 'meaningless' and 'grossly wrong'.

\section{Comment 10}

Joy et al. (2018), discuss the work by Patil Pillai et al. (2018) and the Ar-Ar geochronology of the Mallapur Intrusive (in sections 3 and 7.3). The study by Patil Pillai and Kale (2019) postdates Joy et al. (2018) and is therefore not referenced. There is no geochronology data used in either Patil Pillai. et al. (2018) or Patil Pillai and Kale (2019), apart from the not so accurate (according to the critique) lower limit proposed by Padmakumari et al. (1998) for 
the age of deposition of the Kaladgi Basin sedimentation. The high-quality ID-TIMS baddeleyite age of the dolerite intrusive reported by Joy et al. (2018), clearly demonstrates the depositional age of the Kaladgi Group to be older than $1861 \mathrm{Ma}$. We have made this clear in our discussion and conclusion sections (sections 7 and 8).

We welcome additional research to enhance the geological understanding on the formation and evolution of the Proterozoic basins in India and recommend constructive dialogue rather than merely dismissing research as "dubious". We have presented the data and proposed an interpretation based on the data, with which we hope to enhance the geological understanding of the Kaladgi and Bhima basins in southern India.

\section{REFERENCES}

Brannon, J.C., Cole, S.C., Podosek, F.A., Ragan, V.M., Coveney, Jr, R.M., Wallace, M.W., \& Bradley, A.J. (1996). Th-Pb and U-Pb dating of ore-stage calcite and Paleozoic fluid flow. Science, 271, 491-493.

Jayaprakash, A.V. (2007). Purana basins of Karnataka. Geological Survey of India Memoir, 129, 1-135.

Joy, S., Patranabis-Deb, S., Saha, D., Jelsma, H., Maas, R., Söderlund, U., Tappe, S., van der Linde G., Banerjee, A., \& Krishnan, U. (2018). Depositional history and provenance of cratonic "Purana" basins in southern India: A multipronged geochronology approach to the Proterozoic Kaladgi and Bhima basins. Geological Journal, 1-28. doi:10.1002/gj.3415.

Padmakumari, V.M., Sambasiva Rao, V.V., \& Srinvasan, R. (1998). Model Nd and Rb-Sr ages of shales of the Bagalkot Group, Kaladgi Supergroup, Karnataka. Abstracts: National Symposium on Late Quaternary Geology and Sea level Changes, Cochin University, Kochi, 70.

Patil Pillai, S., \& Kale, V.S. (2019). Interplay between tectonics and eustasy in a Proterozoic epicratonic polyhistory basin: Kaladgi basin, north Dharwar craton. In Mukherjee, S. (Ed.) Tectonics and structural geology: Indian context, (75-114). Springer Geology.

Patil Pillai, S., Pande, K., \& Kale, V.S. (2018). Implications of new ${ }^{40} \mathrm{Ar} /{ }^{39} \mathrm{Ar}$ age of Mallapur Intrusives on the chronology and evolution of the Kaladgi Basin, Dharwar craton, India. Journal Earth System Sciences, 127, $1-32$.

Saha, D., Patranabis-Deb, S., \& Collins, A. (2016). Proterozoic stratigraphy of Southern India cratons and Global context, Stratigraphy \& Timescales, Volume 1, 1-59, Elsevier. http://dx.doi.org/10.1016/bs.sats.2016.10.003

Stille, P., \& Clauer, N. (1994). The process of glauconitization: chemical and isotopic evidence. Contributions to Mineralogy and Petrology, 117, 253-262. 
Table R1: Sample numbers and Locations (decimal degrees, GCS WGS84)

\begin{tabular}{|c|c|c|c|c|c|c|c|c|}
\hline SAMPLE\# & Longitude & Latitude & SAMPLE\# & Longitude & Latitude & SAMPLE\# & Longitude & Latitude \\
\hline EHN678 & 75.66762 & 16.14195 & EHV955 & 76.45595 & 16.38197 & EHV971 & 76.80838 & 17.03605 \\
\hline EHW667 & 75.29789 & 16.16362 & EHV958 & 76.42468 & 16.4565 & EHV974 & 76.78852 & 17.1368 \\
\hline EHV682 & 75.23584 & 16.14684 & EHV959 & 76.51075 & 16.48333 & EHV975 & 76.78852 & 17.1368 \\
\hline EHV 680 & 75.65764 & 15.99126 & EHV963 & 76.99284 & 17.09847 & EHV961 & 76.66347 & 16.74488 \\
\hline EHV683 & 75.23749 & 16.11105 & EHV964 & 76.99284 & 17.09847 & EHV970 & 76.79103 & 17.00084 \\
\hline EHV689 & 75.67759 & 15.93774 & EHV965 & 76.98286 & 17.1078 & EHV973 & 76.76962 & 16.98945 \\
\hline EHV679 & 75.65457 & 16.10182 & EHV966 & 76.98286 & 17.1078 & EHV956 & 76.45443 & 16.39079 \\
\hline EHV951 & 76.10595 & 16.33659 & EHV967 & 76.91764 & 17.00615 & EHV957 & 76.425 & 16.45668 \\
\hline EHV953 & 76.36667 & 16.35886 & EHV968 & 76.89547 & 16.99757 & EHV954 & 76.37083 & 16.3572 \\
\hline EHV962 & 76.79276 & 16.75249 & EHV969 & 76.8327 & 16.99972 & & & \\
\hline
\end{tabular}

This article is protected by copyright. All rights reserved. 


\section{University Library}

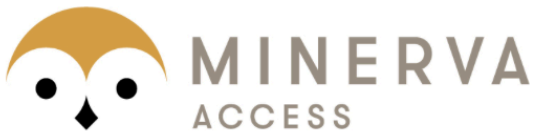

A gateway to Melbourne's research publications

Minerva Access is the Institutional Repository of The University of Melbourne

Author/s:

Joy, S;Patranabis-Deb, S;Saha, D;Jelsma, H;Maas, R;Soderlund, U;Tappe, S;Van der Linde, G;Banerjee, A;Krishnan, U

Title:

Reply to the comments by Pillai, S. P., George, B. G., Ray, J. S., and Kale, V. S., (GJ-19-0112) on Paper: "Depositional history and provenance of cratonic "Purana" basins in southern India: A multipronged geochronology approach to the Proterozoic Kaladgi and Bhima basins" by Joy et al., 2018

Date:

2019-09-01

\section{Citation:}

Joy, S., Patranabis-Deb, S., Saha, D., Jelsma, H., Maas, R., Soderlund, U., Tappe, S., Van der Linde, G., Banerjee, A. \& Krishnan, U. (2019). Reply to the comments by Pillai, S. P., George, B. G., Ray, J. S., and Kale, V. S., (GJ-19-0112) on Paper: "Depositional history and provenance of cratonic "Purana" basins in southern India: A multipronged geochronology approach to the Proterozoic Kaladgi and Bhima basins" by Joy et al., 2018. GEOLOGICAL JOURNAL, 54 (5), pp.3170-3173. https://doi.org/10.1002/gj.3546.

Persistent Link:

http://hdl.handle.net/11343/286011 